\title{
Recalibrating China-U.S. Climate Cooperation Under the Trump Administration
}

Cao Jiahan

\begin{abstract}
Based on the analytical framework of securitization, this article argues that cooperation between China and the United States on climate change will not lose momentum despite President Trump's seemingly passive stance. A securitization process on the climate issue has been ongoing in China since President $\mathrm{Xi}$ Jinping took office and proposed the Overall National Security Outlook (ONSO). Climate security was thus integrated into China's political discourse as a key component of ecological and common security, leading to a period of China-U.S. cooperation during the Obama administration. Similarly, in the United States, climate policy has been cemented in security planning and assessment of various federal agencies. The U.S. security sector seems to be largely unaffected by the White House decision to withdraw from the Paris Agreement.
\end{abstract}

Cao Jiahan is Research Fellow at the Shanghai Institutes for International Studies (SIIS). His mailing address is: 195-15 Tianlin Road, Shanghai 200233, China. He can also be reached at caojiahan@siis.org.cn. The author appreciates the comments from Professor J. Scott Hauger at College of Security Studies, Daniel K. Inouye Asia-Pacific Center for Security Studies (DKI-APCSS), Honolulu, the United States.

(c) 2018 World Century Publishing Corporation and Shanghai Institutes for International Studies China Quarterly of International Strategic Studies, Vol. 4, No. 1, 77-93

DOI: $10.1142 / S 2377740018500033$

This is an Open Access article, copyright owned by the SIIS and WCPC. The article is distributed under the Creative Commons Attribution 4.0 (CC BY-NC) Licence. Further distribution of this work is permitted, provided the original work is properly cited and for non-commercial purposes. 
A growing number of Americans treat climate change as a security threat and many U.S. states and cities, in collaboration with business leaders, have taken on a role in international climate diplomacy. Combined with existing intergovernmental collaborative projects, robust market forces and innovative local initiatives will continue to push China-U.S. climate cooperation forward. As a necessary step to sustain its ties with the United States on climate issues, the Chinese government needs to propose a renewed bilateral framework on energy and environment cooperation under the China-U.S. Comprehensive Economic Dialogue.

Keywords: Climate change; securitization; Overall National Security Outlook (ONSO); Donald Trump; China-U.S. relations.

On June 1, 2017, U.S. President Donald Trump formally announced that the United States would withdraw from the Paris Agreement on climate change, which was perceived to be a huge blow to the ongoing bilateral and multilateral climate diplomacy. The rollback of climate policy by the Trump administration has, to some extent, weakened the U.S.' leadership and triggered worldwide concerns about how to advance international efforts on climate mitigation and adaptation. Against this backdrop, the onceremarkable China-U.S. climate cooperation has been eclipsed by an emphasis on energy trade that caters to President Trump's "America First" rhetoric and will no longer be prioritized as a pillar of their bilateral relations, at least at the summit level.

While a great number of observers feel doubtful about the future of China-U.S. climate cooperation, this paper adopts a more optimistic perspective. The first part attempts to reveal that the success of China-U.S. climate cooperation during the Obama era can largely be attributed to the securitization of climate change issues in China, particularly after President Xi Jinping assumed power and proposed the Overall National Security Outlook (ONSO). It then elaborates on the dynamics of U.S. climate policy under the Trump administration and questions whether President Trump's policy shift has brought significant changes in the security planning and assessment of U.S. federal agencies as well as the perception of American people. The third section looks into the challenges and opportunities for future China-U.S. climate cooperation. The paper concludes with policy recommendations on how the Chinese government can find new opportunities to sustain its ties with the United States on climate issues. 


\section{Securitization of Climate Change in China}

As the world's two single largest greenhouse gas emitters, China and the United States have been working closely and constructively to address climate challenges over the past few years. It was widely acknowledged that the robust cooperation between the two countries catalyzed the success of the 2015 Paris climate change conference. In history, however, climate change was for a time a source of their bilateral disputes. The China-U.S. standoff over emission cuts and funding mechanisms during the Copenhagen climate talks in 2009 provides a good reminder that may help understand the divergent views of both countries.

In the United States, the implications and impacts of climate change have unprecedentedly grabbed the attention of policymakers since 2007. With the facilitation of some "knowledge translators," i.e., strategic analysts, policymakers as well as policy practitioners, and the like, climate change has gone beyond the fields of meteorology and atmospheric science and finally become a keyword of various securitization statements by the U.S. security sector. ${ }^{1}$ By contrast, the Chinese government used to deal with climate issues from the perspective of economic development, which was increasingly in tension with the U.S. perception of climate change as a security issue. ${ }^{2}$ Consequently, the United States worked to securitize cli-

China and the U.S.

used to hold

divergent views on

whether climate

change should be

regarded as a security issue. mate change at the international level and to label China as a major "threat" to the global environment. At that time, China also found itself in fierce competition with the United States and showed no willingness to yield on considering climate change as a security issue. $^{3}$

To many people's surprise, China and the United States achieved a compromise in

${ }^{1} \mathrm{~J}$. Scott Hauger, “Climate Change and the U.S. Security Sector: The Securitization of Climate Change," International Security Studies, Vol. 2, No. 2 (2016), pp. 88-108.

${ }^{2}$ Zhou Lihua et al., "Perceptions of Climate Change in China: The Research and Policy Connection," Sciences in Cold and Arid Regions, Vol. 6, No. 2 (2014), pp. 89-98.

${ }^{3}$ Pan Yaling, Securitization and Evolution of U.S. Strategy towards China in the Post-Cold War Era (Shanghai: Fudan University Press, 2016), pp. 234-251. 
2013. In April that year, the two countries established a joint working group to promote climate cooperation based on a consensus between President Xi Jinping and President Obama. China-U.S. cooperation culminated in a series of joint presidential statements on climate change from 2014 to 2015. Both countries pledged to drastically cut greenhouse gas emissions by 2030, which greatly boosted the confidence of other countries and encouraged them to make their own national commitments on climate actions.

When people talk about the success story of bilateral climate cooperation during the Obama era, they tend to disregard the securitization process of climate change in China, which actually contributed to the narrowing of their policy difference and finally led to their bilateral consensus. Similar to what happened in the United States, knowledge of and concerns about climate change in China were traditionally generated in the scientific community. However, due to the lack of "knowledge translators," the Chinese security sector had relatively little awareness on issues of climate change. Although the Defense White Paper (DWP) drafted by China's Ministry of National Defense (MND) in 2008 and 2010 referred to "climate change" as one of the "global challenges," ${ }^{4}$ they did not actually factor it into the planning and impact assessment of the Chinese security sector. Meanwhile, China's mounting environmental problems, from air pollution in Beijing to water-related disasters in the far western provinces, have become real threats to the country's sustainable economic growth and political legitimacy of the Communist Party of China (CPC).

Since Xi Jinping took office as Secretary General of the CPC in November 2012 and Chinese President in March 2013, one of his famous judgments, "Clear waters and green mountains are invaluable assets," has been reemphasized as the fundamental principle of China's ecological development. ${ }^{5}$ Accordingly, climate change has been further scrutinized and officially incorporated into China's security agenda as a significant component of ecological security and common security. In November 2013, the

\footnotetext{
${ }^{4}$ See respectively Information Office of the State Council, "China National Defense in 2008," January 2009, http://english.gov.cn/official/2009-01/20/content_1210227.htm; and “China's National Defense in 2010," March 2011, http://english.gov.cn/archive/white_paper/ 2014/09/09/content_281474986284525.htm.

${ }^{5} \mathrm{Xi}$ Jinping, "Clear Waters and Green Mountains are Invaluable Assets," in Xi Jinping, The Governance of China II (Beijing: Foreign Languages Press Co. Ltd, 2017), pp. 426-427.
} 
newly minted Chinese leadership headed by President Xi made a pivotal decision to set up the National Security Commission (NSC) under the CPC Central Committee to oversee China's national security institutions and strategies, with $\mathrm{Xi}$ himself serving as Chairman of the Commission. In April 2014, President Xi proposed the Overall National Security Outlook (ONSO) on the first NSC plenary meeting as "the general guidance for China's national security work for the new era." 6

Compared with traditional security ideologies, the ONSO takes a more comprehensive, integrated and holistic approach to overcome fragmentation and separation of security governance in different sectors. It emphasizes that traditional and non-traditional security threats can be mutually affected and exacerbated under certain conditions. In particular, non-traditional security threats like climate change can create huge impacts on human security. Also, it highlights the significance of common security in a globalized and interdependent world. Without global vision and joint efforts with other countries, China cannot put up an effective fight against cross-border security threats. Thus, China needs to proactively strengthen international security cooperation to achieve common security, so that all countries can enjoy a universal, equal and inclusive security environment.

Moreover, the ONSO lays out 12 most relevant security fields, in terms of politics, territorial integrity, military, economy, culture, society, science and technology, cyberspace, ecology, resources, nuclear, and overseas interests. Notably, ecological security was unprecedentedly singled out as an independent part of China's national security framework; and climate change, in parallel with water shortage, air pollution and desertification, is considered a prominent challenge to ecological security. According to China's Third National Climate Change Assessment Report (NCCAR3) published in November 2015, climate change is the culprit behind the country's extreme weather events; it has led to negative effects on food production and quality, water resources, oceanic environment and ecology. ${ }^{7}$

Dr. Zhang Haibin, a Peking University professor whose research has been focused on China's climate security, argues that climate impact goes well beyond the ecological system to reach a number of other security

6"Xi Stresses Importance of National Security," China Daily, April 15, 2014, http://www. chinadaily.com.cn/china/2014-04/15/content_17436440.htm.

${ }^{7}$ China's Third National Climate Change Assessment Report, (Beijing: Science Press, 2015). 
spheres listed in the ONSO. First of all, the problem of rising sea levels, driven by global warming, has been accelerating in China's coastal regions, this increases flood risks to territories in the Yangtze and Pearl Deltas. Secondly, climate change and extreme climate incidents could undermine the performance of the People's Liberation Army (PLA)'s military personnel and equipment. Thirdly, climate change presents growing threats to agriculture, urban development, transportation, infrastructure, grid, nuclear and other energy facilities. Last but not the least, climate change, through its impact on territorial, military, social, economic, resource, and nuclear security, will generate governance challenges that could shatter people's faith in the government and jeopardize political stability in China. ${ }^{8}$

As a result, China has finally chosen a security frame on climate change and begun to view pressing environmental issues - most of which are impacted by climate change - as catalysts to political insecurity. Just as President $\mathrm{Xi}$ warned at a routine Politburo Standing Committee (PSC) meeting in April 2013, en-

The climate issue has been securitized in China under President Xi's leadership. vironmental protection should not merely be taken as an economic issue; in fact, it has many political ramifications. ${ }^{9}$ Soon after President $\mathrm{Xi}^{\prime}$ s remarks at the PSC meeting, the PLA's General Logistics Department (GLD) for the first time organized military meteorologists and hydrologists to give several touring lectures in the Army, Navy, Air, and Rocket Forces, to improve their disaster preparedness and comprehensive capability to address climate risks. Based on the guiding principles of the ONSO, China's National People's Congress (NPC) adopted the revised National Security Law in July 2015, which includes ecological and environmental protection as one of the key tasks to safeguard national security.

${ }^{8}$ Zhang Haibin, "Qihoubianhua dui zhongguo guojiaanquan de yingxiang - cong zongti guojiaanquanguan de shijiao [Implications of Climate Change on China's National Security: A Perspective of Overall National Security Outlook]," International Politics Research, Vol. 4 (2015), pp. 11-36.

9"Xi Jinping shibada yilai guanyu 'shengtaiwenming' lunshu zhaibian [Xi Jinping Remarks on Ecological Civilization]," CPC News, August 26, 2014, http://cpc.people.com.cn/n/2014/ 0826/c164113-25542941.html. 
At the 19th CPC National Congress held in October 2017, President Xi further prioritized environmental protection in his long and dense report with a full chapter on "developing ecological civilization and building beautiful China," in which "promoting green development," "solving prominent environmental problems," "intensifying the protection of ecosystems," and "reforming the environmental regulation system" were emphasized as priority areas for the coming years. Though President Xi did not mention climate change directly in that chapter, he actually identified a wide range of typical climate-driven problems faced by China today, and vowed to vigorously cultivate a green, low-carbon and circular economy as a solution to those problems. More importantly, President Xi reaffirmed China's commitments and targets on cutting greenhouse gas emissions, which implies that the country is fully aware of the significance as well as its own responsibility in ensuring national and international climate security.

Besides, in another separate chapter on foreign policy and global governance, President $\mathrm{Xi}$ explicitly named climate change, along with other non-traditional security threats such as terrorism, nuclear proliferation, epidemics and cyber-attacks, as common challenges for human society. ${ }^{10}$ He again called for enhanced global security cooperation to tackle climate change. In March 2018, China announced a sweeping overhaul of government institutions during the "Two Sessions (CPC and the Chinese People's Political Consultative Conference, or the CPPCC)" meetings in Beijing, and the Ministry of Ecological Environment (MEE) was set up to take over the responsibility for combating climate change and carbon emission reduction from the powerful economic planning body, National Development and Reform Commission (NDRC), another sign of mindset change on climate issues.

It is quite evident that during the past five years, climate change, traditionally understood as an economic or development issue, has been endowed with a multitude of security and political implications in China. We have seen an accelerated securitization process on climate change, which is frequently referred to as a key element of ecological and common security in China's political discourse. This remarkable policy shift initiated

10“Full Text of Xi Jinping's Report at 19th CPC National Congress," China Daily, October 18, 2017, http://www.chinadaily.com.cn/china/19thcpcnationalcongress/2017-11/04/ content_34115212.htm. 
by President Xi himself is doubtlessly conducive to better alignment of China's national interests in environmental sustainability with its international obligations on climate security. The security rhetoric on climate change in China is unlikely to be reversed in President Xi's second 5-year term starting from 2018. On the domestic front, China will continue to leverage its financial and technological resources to achieve ecological security, with a focus on trying to reverse the rising curve of emissions as early as possible. On the international front, China's contribution will be well anticipated and recognized given the current political stances of Trump's America.

\section{Climate Change on the U.S. Security Agenda}

Widely recognized as the best "climate president" in U.S. history, Barack Obama had made the United States a world leader on combating climate change. ${ }^{11}$ Under his presidency, climate change was prioritized on the U.S. national security agenda: the 2015 U.S. National Security Strategy (NSS) published by the Obama administration clearly identified climate change as one of the eight top strategic risks to American national security. ${ }^{12}$ Unfortunately, Obama's climate legacy seems to have been largely dismantled by his successor.

Even during his campaign for president, Donald Trump was infamous for his ignorance of the reality of global warming, which he denounced as a "Chinese plot" and a hoax. Soon after inauguration, he officially picked Scott Pruitt, a climate change denialist and key architect of the legal battle against Obama's climate policies, as head of the U.S. Environmental Protection Agency (EPA). Domestically, President Trump quickly rolled back the Clean Power Plan and other environmental programs initiated by his predecessor; internationally, in an unpopular move, he announced the U.S. withdrawal from the Paris Agreement. In the latest NSS released in December 2017, climate change has unsurprisingly been removed from the list

${ }^{11}$ John Abraham, "Barack Obama is the First Climate President," Guardian, November 2, 2016, https://www.theguardian.com/environment/climate-consensus-97-per-cent/2016/ nov/02/barack-obama-is-the-first-climate-president.

${ }^{12}$ The White House, National Security Strategy, February 2015, https://obamawhitehouse.archives.gov/sites/default/files/docs/2015_national_security_strategy.pdf. 
of national security threats. ${ }^{13}$ All of these indicate that climate issues are no longer highlighted on the U.S. security agenda.

\section{The Trump}

administration

downplays the

security implications

of climate change

mainly for economic

considerations.

Admittedly, the Trump administration has chosen to adopt a pragmatic approach to climate change by viewing it through the lens of economic development. To President Trump, taking actions to reduce carbon dioxide emissions will undermine abundant opportunities for the revival of the fossil fuel industry, jeopardizing U.S. energy independence and the overall economy in the long run. Consequently, he unwound Obama's rules and regulations on coal mining, cleared the way for the construction of Keystone XL pipelines, and opened up the U.S. continental shelf to oil exploitation. In January 2018, the National Aeronautics and Space Administration (NASA) confirmed that the oil and gas industry is primarily responsible for the increase of methane emissions, which has sped up climate change. ${ }^{14}$ However, President Trump's "America First Energy Plan" totally shrugged off the climate impact of fossil fuel development and thus sparked increasing concerns within Washington's political elites, many of whom treat climate change as a major security threat.

Even among ordinary Americans, beliefs about climate change and global warming remain fairly stable in the past few years. Several Pew Research Center surveys show that roughly 50 percent of American adults think climate change is mostly a result of human activities. ${ }^{15}$ Meanwhile, support for taking actions to address climate change in the United States has been growing after Donald Trump took office. The Chicago Council on

${ }^{13}$ The White House, National Security Strategy of the United States, December 2017, https://www.whitehouse.gov/wp-content/uploads/2017/12/NSS-Final-12-18-2017-0905.pdf.

${ }^{14}$ Leila Mead, "NASA Confirms Methane Increase Linked to Oil and Gas Industry," International Institute for Sustainable Development, January 23, 2018, http://sdg.iisd.org/ news/nasa-confirms-methane-increase-linked-to-oil-and-gas-industry/.

${ }^{15}$ Pew Research Center, "Public Views on Climate Change and Climate Scientists," October 4, 2016, http://www.pewinternet.org/2016/10/04/public-views-on-climate-changeand-climate-scientists/. 
Global Affairs recorded in its 2017 survey the highest concern from Americans who say climate change is a security threat faced by the United States. ${ }^{16}$ Hurricanes Harvey and Irma that pummeled the United States in the summer of 2017 further aggravated people's concern despite President Trump's dismissal of the link between climate change and natural disasters.

Given this background, two camps with utterly opposing views on climate policies within the Trump administration are taking shape. On one side, after announcing the U.S. withdrawal from the Paris Agreement, President Trump has led the White House to eliminate new climate satellites, reneged on his predecessor's $\$ 2$ billion commitment to the Green Climate Fund, and slashed funding for climate programs of the EPA, the Department of State (DoS), and the United States Agency for International Development (USAID). On the other side, the Department of Defense (DoD), mandated by the Republican-controlled Congress which affirms that climate change is a prominent national security threat, is taking a close look at how climate change is going to affect key military installations; in the meantime, it has considerably increased the military budget to deal with the threat. ${ }^{17}$

When President Trump announced his NSS that does not take climate security into account, a group of Congressional legislators felt extremely concerned. According to a report by the U.S. Government Accountability Office (GAO), "a three-foot rise in sea levels will threaten the operations of more than 128 U.S. military sites, and it is very possible that many of these at-risk bases could be submerged in coming years." ${ }^{18}$ As a result, the DoD is poised to be a champion of climate actions in the Trump administration. Although President Trump made up his mind to withdraw from the Paris Agreement, top military and civilian officials at the Pentagon, including

${ }^{16}$ Dina Smeltz et al., "What Americans Think About America First?," Chicago Council on Global Affairs, October 2, 2017, https://www.thechicagocouncil.org/publication/whatamericans-think-about-america-first.

${ }^{17}$ Sean Mowbray, "A Tale of Two Policies: Climate Change, Trump, and the U.S. Military," Mongabay, January 17, 2018, https://news.mongabay.com/2018/01/a-tale-of-two-policies-climate-change-trump-and-the-u-s-military/.

${ }^{18}$ Scott Wyland, "Climate Change Risks Include 128 Military Sites Threatened by Rising Sea Levels, GAO Says," Stars and Stripes, December 22, 2017, https://www.stripes. com/news/climate-change-risks-include-128-military-sites-threatened-by-rising-sea-levelsgao-says-1.503589. 
James Mattis, President Trump's own Defense Secretary, still believe that climate change poses a grave threat to the U.S. national security and the world's stability at large. Secretary Mattis has spoken out about the perils of climate change, running contrary to his commander-in-chief. As he told the Senate Armed Services Committee, climate change would make the world less stable. He called for the entire government to address its impact. ${ }^{19}$ Analysts thus expect that the U.S. military will continue with its climate adaptation and disaster preparedness programs, despite the President's skepticism.

In a similar vein, the U.S. intelligence community under the Trump administration also views climate change as a national security concern. In contrast with the NSS released in December 2017 and the National Defense Strategy (NDS) published in January 2018, the annual summary report of global threats, which was issued in February 2018 by several leading U.S. intelligence agencies including the Federal Bureau of Investigation (FBI), the Central Intelligence Agency (CIA), the Defense Intelligence Agency (DIA), and the National Security Agency (NSA), concludes that "the impacts of the long-term trends toward a warming climate, more air pollution, biodiversity loss and water scarcity are likely to fuel economic and social discontent — and possibly upheaval — through 2018." ${ }^{20}$

The U.S. security

sector regards

climate change as a

national security

threat despite

President Trump's

policy shift.
Therefore, within the U.S. security sector, at least the military and the intelligence community, no conspicuous change has been found so far in their stance toward climate change. In fact, since 2007 when Sherri Goodman, former Deputy Undersecretary of Defense in the Clinton administration, first coined the phrase "threat multiplier" in a Center for Naval Analysis (CNA) report, the U.S. security sector has been legitimizing its

${ }^{19}$ Alex Ward, "Experts to Trump: Climate Change Threatens the US Military," Vox, June 5, 2017, https://www.vox.com/2017/6/5/15729426/paris-agreement-climate-changemilitary.

${ }^{20}$ Daniel R. Coats, Worldwide Threat Assessment of the US Intelligence Community, February 13,2018 , p. 16. https://www.intelligence.senate.gov/sites/default/files/documents/osdcoats-021318.PDF. 
concern with climate change by making it a standard term in a series of securitization documents, including the DoD's 2010 Quadrennial Defense Review (QDR), its 2010 Quadrennial Diplomacy and Development Review (QDDR), and the two "Climate Change Adaptation Roadmaps" issued by the DoD in 2012 and 2014. ${ }^{21}$ Over time, this decade-long securitization process has cemented climate change as a key issue in the process of security planning and assessment of the U.S. federal agencies.

\section{Future Prospects of China-U.S. Climate Cooperation}

Needless to say, President Trump's decision to pull his country out of the Paris Agreement in June 2017 has created numerous uncertainties for the U.S. climate commitment as well as for global climate governance. A large number of policymakers and academics worldwide have wondered about the impact of this decision, some of whom have expressed fears that it would paralyze ongoing bilateral and multilateral climate diplomacy. Likewise, many observers feel pessimistic about the future of China-U.S. climate cooperation, which seems to have lost momentum after President Trump took office. Is such cooperation - once highlighted in China-U.S. relations - coming to an end?

Certainly, President Trump's withdrawal from the Paris Agreement has brought serious challenges to China-U.S. climate cooperation. As the Trump administration has signaled its lack of political will to participate in the multilateral climate process and slashed its financial investment in international climate actions, China-U.S. climate cooperation may become less institutionalized than during the Obama era. For example, soon after President Trump announced his decision, the U.S. Department of Energy (DoE) reshuffled its organizational structure and closed the Office of International Climate and Technology, which was formed in 2010 to help the United States provide technical assistance to other nations seeking to reduce greenhouse gas emissions. Notably, this small office has played a leading role in preparing the annual Clean Energy Ministerial, a forum in which the United States, China, and some other countries shared insights on how to promote energy efficiency, electric vehicles and other solutions to

\footnotetext{
${ }^{21}$ Hauger, "Climate Change and the US Security Sector: The Securitization of Climate Change."
} 
climate change. ${ }^{22}$ The 23rd Conference of the Parties (COP23) to the United Nations Framework Convention on Climate Change (UNFCCC) held in Bonn in November 2017 also saw an unprecedentedly small official U.S. delegation that largely ignored the conventional multilateral negotiation.

China-U.S. climate cooperation is less institutionalized in the Trump era.
At the bilateral level, the China-U.S. Climate Change Working Group (CCWG), one of the most significant legacies of ChinaU.S. relations in the Obama era, was not incorporated into the four Comprehensive Dialogues between both countries set up by President $\mathrm{Xi}$ and President Trump on their meeting at Mar-a-Lago in April 2017. The suspension of CCWG operations could slow down the implementation process of existing collaborative projects, including "emission reductions from heavy-duty and other vehicles," "smart grids," "carbon capture, utilization and storage (CCUS)," "collecting and managing greenhouse gas emissions data," "energy efficiency in buildings and industry," "smart cities," "climate change and forest," and "boiler efficiency and fuel switching," among others. ${ }^{23}$ For instance, collecting greenhouse gas emissions data has become more difficult today in the United States as the Trump administration deregulates the fossil fuel industry and re-prioritizes missions of the EPA, which could undermine the U.S. capability to share with China its expertise and experience in implementing a successful national greenhouse gas reporting program. In addition, uncertainties also linger over the future direction of some other bilateral projects that may fall into stagnation.

Despite these challenges, we can still find some reasons to stay positive. In the first place, robust market forces will be key drivers to scale up bilateral cooperation on climate change. Since China is now promoting its overall competitiveness through adopting new development models of low-carbon, resource-light prosperity, huge demand for low-carbon

${ }^{22}$ Brad Plumer, "Energy Department Closes Office Working on Climate Change Abroad," New York Times, June 15, 2017, https://www.nytimes.com/2017/06/15/climate/energy-department-closes-office-working-on-climate-change-abroad.html.

${ }^{23}$ Report of the US-China Climate Change Working Group to the 6th Round of the Strategic and Economic Dialogue (Beijing: National Development and Reform Commission, July 2014), http://en.ndrc.gov.cn/newsrelease/201407/P020140710297942139135.pdf. 
technologies and capacity-building has been created and enormous market potentials will be unleashed in the longer term. As a rather complex and multifaceted problem, climate change can only be tackled in China through the combination of top-down and bottom-up approaches. Against this backdrop, U.S. companies and research institutions with technological advantage and experience will gain increasing prominence in China. These non-governmental actors are expected to take actions based on their own value systems and business interests, expanding their share in China's green market, regardless of diminished political and financial support from the federal government. ${ }^{24}$ It is quite hopeful that China and the United States can achieve strong synergies in the private sector to combat climate change.

Secondly, local governments in the United States have been playing an important role in international climate diplomacy. At the state level, governments are still committed to clean-energy, pollution control and emission reduction. For example, at a side event of the 2017 Bonn climate conference titled "Filling the Void: U.S. State-Driven Climate Leadership," Oregon governor Kate Brown expressed her concern that climate impacts would exacerbate existing economic disparities and described the development of a carbon pricing strategy. Washington governor Jay Inslee regarded climate change as the largest economic opportunity since the invention of the steam engine. California governor Jerry Brown put much hope in the Global Climate Action Summit to be held in San Francisco in September 2018, which will bring together sub-national actors from cities, federal states and corporations to discuss their climate commitments and action plans. ${ }^{25}$

At the municipal level, institutional arrangements for emission reduction such as the C40 Cities Climate Leadership Group and the Compact of Mayors are still functioning, in which a number of U.S. cities

${ }^{24}$ Tang Wei, “US-China Climate Cooperation in the Trump Era," China Dialogue, July 5, 2017, https://chinadialogue.net/blog/9900-US-China-climate-co-operation-in-the-Trumpera/en.

${ }^{25}$ Leila Mead, "COP 23 Side Events Address Subnational Climate Action in the US," International Institute for Sustainable Development, November 14, 2017, http://sdg.iisd.org/ news/cop-23-side-events-address-removal-of-fossil-fuel-subsidies-subnational-climate-action-in-the-us-13-november-highlights/. 
are involved. Michael Bloomberg, former mayor of New York City, also chaired the Global Covenant of Mayors in Bonn in November 2017 to explore the role of cities in putting the Paris Agreement into practice. In his role as United Nations Secretary-General's Special Envoy for Cities and Climate Change, Michael Bloomberg recently announced his decision to donate $\$ 4.5$ million to the UNFCCC to make up for the shortfall in the agency's budget caused by funding cuts of the Trump administration.

Therefore, even without the support of the federal government, ChinaU.S. climate cooperation can continue to deepen at the local level. It is imaginable that "smart cities," one of the few collaborative projects initiated by the China-U.S. CCWG, will not only survive but even thrive during the Trump administration. In December 2017, the Chinese government launched the process to design and implement a national carbon emission trading system (ETS). Once actual trading starts around 2020, the ETS is likely to become the world's largest, surpassing its counterpart in the European Union (EU). In the long run, establishment of linkage between China's carbon market and a similar scheme in California and other U.S. states could be a new initiative of climate cooperation between China and the United States.

American cities,

states and businesses

can advance

China-U.S. climate

cooperation even

without federal

support.
Finally, bilateral climate cooperation can be revitalized under the existing U.S.-China Framework for Ten Year Cooperation on Energy and Environment (FTYCEE) reached in 2008 during the G. W. Bush presidency. Within the framework of the FTYCEE, China and the United States have set up a joint steering committee and several working groups to prioritize their collaboration in fields like clean air, clean water, clean and efficient transportation, as well as energy efficiency, which are much broader than those under the CCWG. Thus, the FTYCEE was in effect in the Obama era, another parallel track for the CCWG. Thanks to many overlapping functions between the two mechanisms, the FTYCEE and the CCWG have long been reinforcing each other and sometimes, the FTYCEE was marginalized due to Obama's preference for climate topics. Yet the role of the FTYCEE has been reemphasized after the removal of the CCWG by the Trump administration. Although many 
Republicans in the U.S. Congress tend to deny climate change as a scientific fact, they nonetheless encourage domestic innovation and international cooperation on energy and environment technologies, which may present new opportunities for joint climate efforts between China and the United States.

\section{Conclusion}

Based on the analytical framework of securitization, this paper argues that China-U.S. climate cooperation will not lose momentum despite some apparent constraints from the Trump administration, and that more cooperation on climate issues is expected between both countries in the future. Major driving forces derive from the multiple political discourse and institutions on climate security in both countries. In China, we have witnessed a securitization process on the climate topic especially after President Xi Jinping took office in late 2012 and proposed the ONSO. Climate security was finally absorbed into China's political discourse as a key component of ecological and common security, which resulted in successful cooperation with the United States during the Obama administration.

In the United States, the reversal of climate policy made by the Trump administration looks dramatic. But in fact, it is quite superficial. Although President Trump has announced the U.S. withdrawal from the Paris Agreement, it is not at all clear whether he has an established idea about the security aspects of climate change. Also, it is very obscure as to how important the White House policy will be in light of the contrary opinions from such executive agencies as the DoD, DoS, and USAID. Climate change has been integrated in the security planning and assessment of U.S. federal agencies. With much support from the Republican-controlled Congress and the broad public opinion, the U.S. security sector seems to be unaffected by the White House decision. More importantly, the election of President Trump has not altered the basic perception on climate change in American society and thus cannot prevent states, cities, and businesses from taking actions. Indeed, a growing number of Americans have realized that climate change is a security threat and many U.S. states and cities, in collaboration with business leaders, have taken the lead in pursuing the climate commitments pledged by the Obama administration. 
In short, we have abundant reasons to remain optimistic about future climate cooperation between China and the United States, because robust market forces and innovative local initiatives, combined with existing intergovernmental collaborative projects, will continue to drive the bilateral cooperation forward. Despite the reluctance of President Trump on climate cooperation, China can still make an attempt to shape his ideas. Since the FTYCEE is about to expire in 2018, the Chinese government needs to take this opportunity to propose a renewed bilateral framework on energy and environment cooperation under the China-U.S. Comprehensive Economic Dialogue, as a necessary step to sustain its ties with the United States on climate issues. 